\title{
Evaluation of breath alcohol analysers by comparison of breath and blood alcohol concentrations
}

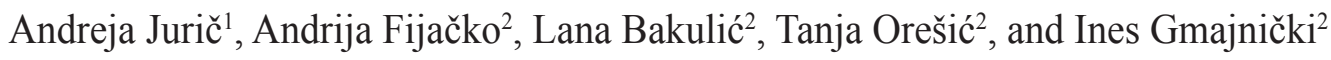 \\ Institute for Medical Research and Occupational Health ${ }^{1}$, Forensic Science Centre Ivan Vučetić, Ministry of the \\ Interior ${ }^{2}$, Zagreb, Croatia
}

[Received in October 2017; Similarity Check in October 2017; Accepted in March 2018]

\begin{abstract}
The main goal of this study was to determine the reliability of hand-held breath alcohol analysers currently approved for roadside screening of traffic offenders. The first part of the study included a retrospective data analysis of 714 offence records collected in 2011. Blood alcohol concentrations (BAC) obtained from the offenders 0-303 min after the police had screened them for breath alcohol concentration (BrAC) were back-calculated (cBAC) to assess the accuracy of breathalyser screening. All participants were in the alcohol elimination phase, and our analyses did not reveal any significant differences between $\mathrm{cBAC}$ and $\mathrm{BrAC}$. To verify our findings, we performed a controlled drinking study that involved 63 healthy volunteers who consumed alcoholic beverages to simulate real drinking conditions. Immediately after alcohol consumption, BrAC was determined with a Dräger breath alcohol analyser model 6810, and 29 participants gave blood and urine sample for concomitant $\mathrm{BAC}$ analysis one hour later. $\mathrm{BAC}$ and urine alcohol concentrations were determined with headspace gas chromatography. Again, we found no significant differences between BrAC and BAC. These results confirmed the high reliability of breath alcohol analysers for measuring $\mathrm{BrAC}$ as long as police officers perform the measurements according to the manufacturer's instructions.
\end{abstract}

KEY WORDS: breathalyser; back calculation; ethanol; elimination factor; gas chromatography, reliability

In Croatia, the first method to screen for drivers or committers of criminal offenses under the influence of alcohol is by measuring breath alcohol concentration $(\mathrm{BrAC})$. The police currently use the Dräger breath alcohol analyser model $7410^{\text {Plus }}$ and the newer model 6810 (Dräger Safety AG \& Co, Lübeck, Germany) that measure BrAC on the spot. According to the Croatian Road Traffic Safety Act (1), the legal limit for BrAC nowadays is $0.50 \mathrm{~g} \mathrm{~kg}^{-1}$, although a few years ago, $>0 \mathrm{~g} \mathrm{~kg}^{-1}$ was considered a traffic offence.

The Croatian Ministry of the Interior reported 39227 driving offenses and 1751 criminal offenses in Croatia in 2011 , in which BrAC was measured. In 2015, these numbers were 41071 driving offenses and 1471 criminal offenses $(2,3)$.

Breath alcohol measurements are based on the fact that about $5 \%$ of the consumed alcohol ends up in the air exhaled from the lungs, where it gets by diffusion from pulmonary capillaries. The concentration of alcohol in expired air can be expressed in $\mathrm{mg} \mathrm{L}^{-1}, \mathrm{~g} \mathrm{~kg}^{-1}$, or \%. In theory, the amount of alcohol in the breath corresponds to an amount of alcohol in the blood. The conversion factor for the Dräger breath alcohol analyser models $7410^{\text {Pus }}$ and 6810 is 1:2100, which means that $2100 \mathrm{~mL}$ of exhaled air (representing arterial blood) contains the same amount of

Correspondence to: Andreja Jurič, Analytical Toxicology and Mineral Metabolism Unit, Institute for Medical Research and Occupational Health, Ksaverska cesta 2, 10000 Zagreb, Croatia, E-mail: ajuric@imi.hr alcohol as $1 \mathrm{~mL}$ of blood $(4,5)$. Breath alcohol analysers use an electrochemical sensor that reacts only to ethanol. This means that it does not react to the ketone group which includes acetone found in the exhaled air of diabetics or people who fast.

Breath analysis is usually made on the spot. If a laboratory blood test is necessary, either alone or to verify the breathalyser findings, it mainly involves gas chromatography. This test makes it possible to back track the blood alcohol concentration (BAC) to the moment of $\mathrm{BrAC}$ screening or accident. This procedure is called back calculation of the blood alcohol concentration (cBAC) $(4$, $6)$.

The association between $\mathrm{BrAC}$ and $\mathrm{BAC}$ was investigated in several studies so far (5-14). However, there is still a debate regarding the reliability of the $\mathrm{BrAC}$ use for a retrograde extrapolation of $\mathrm{BAC}$, since some reports indicate potential underestimation, while other point to overestimation of the actual BAC based solely on BrAC measurement.

Most of the studies acknowledge the usefulness of $\mathrm{BrAC}$ measurements for back calculation of BAC (5-7, 9-11) but also point out the issues, principally related to the accuracy of the instrument used, and time delay between breath and blood analysis. Some studies suggest that BrAC may not always reflect the real concentration of BAC, especially if one takes into account inter-individual variations in alcohol metabolism and specific health conditions $(8,12-14)$. It is, 
therefore, quite legitimate to ask how reliable breath analysers are.

Wishing to contribute to the knowledge about the reliability and performance of breathalysers currently in use in our country, we performed a two-part study of the association between BrAC and BAC. The first part was a retrospective study that involved matched pairs of records on BrAC measurements with Dräger breathalysers and the corresponding cBACs, based on the BACs measured in laboratory with headspace gas chromatography. The second part was a controlled drinking study, which simulated real drinking conditions and involved measurement of BAC simultaneously with BrAC in volunteers. The aim was to verify our findings and establish which factors may contribute to the inconsistencies between $\mathrm{BrAC}$ and $\mathrm{cBAC}$, such as sex differences in alcohol elimination over time.

\section{MATERIALS AND METHODS}

\section{Participants and study design}

The first, retrospective part of our study included analysis of the paired breath and blood alcohol records of 714 offenders from 2011, retrieved from the archive of the Forensic Science Centre Ivan Vučetić (Zagreb, Croatia). For the purpose of this study we used anonymous, coded data. The use of these records for scientific purposes was approved by the Centre (15).

The second part of our investigation was a controlled drinking study with 63 healthy adult volunteers (21 men and 42 women, aged from 26 to 61 years), who gave their informed consent to participation in the study. It was divided in two stages. Stage 1 included all 63 subjects. They consumed different types of alcoholic beverages, which contained 15-44 \% v/v of ethanol. Alcohol consumption started in the morning and lasted for two and a half hours. Fifteen minutes after last alcohol consumption, their BrAC was measured with a breathalyser. Concurrently, their venous blood was taken from to measure BAC with headspace gas chromatograph. Blood samples were collected by venepunction into sterile $8.5 \mathrm{~mL} \mathrm{S-Monovette}{ }^{\circledR}$ tubes without anticoagulant (Sarstedt AG \& Co. KG, Nümbrecht, Germany).

Alcohol concentration was also measured in urine to determine the stage of alcohol metabolism. Urine samples were collected into $10 \mathrm{~mL} \mathrm{S-Monovette}{ }^{\circledR}$ tubes.

Stage 2 included 29 participants (10 men and 19 women), who were willing to provide the second sample of BrAC, blood, and urine for alcohol concentration measurement, one hour after the first sampling.

\section{Breath alcohol concentration (BrAC) measurement}

BrAC measurements in the retrospective study were taken by the police on the spot using Dräger Alcotest $7410^{\text {Plus }}$ or 6810 breath alcohol analysers (Dräger Safety AG \& Co, Lübeck, Germany). In the controlled drinking study BrAC was measured with the Dräger Alcotest 6810 model (Dräger Safety AG \& Co, Lübeck, Germany).

These devices can measure across the concentration range from 0 to $5 \mathrm{~g} \mathrm{~kg}^{-1}$ and temperature range from -5 to $50{ }^{\circ} \mathrm{C}$. Limits of error (LE) for breath alcohol analysers are given in Table 1.

\section{Blood alcohol concentration (BAC)}

In the retrospective part of the study, BAC was backcalculated to correspond to the time when BrAC was measured. For the calculation we used the Widmark formula $(17,18)$ :

$$
C_{t_{1}}=C_{t_{2}}+\beta * \Delta t
$$

where $C_{t}$ is the back-calculated BAC (cBAC); $C_{t}$ is BAC determined with headspace gas chromatography; $\beta$ is alcohol elimination factor; and $\Delta \mathrm{t}$ is time elapsed between the blood $\left(\mathrm{t}_{2}\right)$ and breath $\left(\mathrm{t}_{1}\right)$ measurements. For the alcohol elimination factor $\beta$ we used the arithmetic mean $0.15 \mathrm{~g} \mathrm{~kg}^{-1} \mathrm{~h}^{-1}$ of its theoretical range $\left(0.1-0.2 \mathrm{~g} \mathrm{~kg}^{-1} \mathrm{~h}^{-1}\right)$ to compare results with previous research $(8,19)$.

In the second part of the study we measured BAC with a PerkinElmer gas chromatograph (Clarus 500) coupled with a flame ionisation detector (GC-FID-HS) and a TurboMatrix 40 headspace auto sampler (PerkinElmer,

Table 1 Limits of error (LE) for Dräger Alcotest $7410^{\text {Plus }}$ and 6810 (16)

\begin{tabular}{ccc} 
Concentration of alcohol & $\begin{array}{c}\text { LE of the type examination and the } \\
\text { initial verification }\end{array}$ & LE for recalibration \\
\hline $0.000-0.400 \mathrm{mg} \mathrm{L}^{-1}$ & $\pm 0.020 \mathrm{mg} \mathrm{L}^{-1}$ & $\pm 0.032 \mathrm{mg} \mathrm{L}^{-1}$ \\
or & or & or \\
$0.00-0.83 \%$ or & $\pm 0.043 \%$ o & $\pm 0.066 \%$ o \\
\hline $0.400-2.000 \mathrm{mg} \mathrm{L}^{-1}$ & $\pm 5 \%$ & $\pm 8 \%$ \\
or & or & or \\
$0.83-4.17 \% 0$ & $\pm 5 \%$ & $\pm 8 \%$ \\
\hline $2.000 \mathrm{mg} \mathrm{L}^{-1}$ & $\pm 20 \%$ & $\pm 30 \%$ \\
or & or & or \\
$>4.17 \%$ & $\pm 20 \%$ & $\pm 30 \%$ \\
\hline
\end{tabular}


Shelton, CT, USA) following the procedure described elsewhere (20). We used BAC-1 capillary column (30 m x $0.32 \mathrm{~mm}$, ID $1.80 \mu \mathrm{m}$, Restek, Bellefonte, PA, USA). For the analysis, we used $0.1 \mathrm{~mL}$ of blood or urine and $0.2 \mathrm{~mL}$ of $n$-propanol (Merck, Darmstadt, Germany) (used as an internal standard). The standard, control solution of ethanol was prepared in the same way as the samples.

\section{Statistical analysis}

To determine standard deviation (SD), standard error (SE), mean, and $95 \%$ confidence interval (CI) we used OriginLab 8.0 (OriginLab Corporation, Northampton, MA, USA) and to process data we used Microsoft Excel 2010 (Microsoft Corporation, Redmond, WA, USA).

The normality of data distribution was checked with the Shapiro-Wilk test. Student's $t$-test $(\mathrm{n}<30)$ and $\mathrm{z}$-test $(n \geq 30)$ were used to test the differences between $\mathrm{BrAC}$ and $\mathrm{BAC}$ (or $\mathrm{cBAC}$ ) and between alcohol elimination factor $\beta$ calculated for expired air and blood, as well the difference in alcohol elimination between men and women (for expired air and blood).

In the linear regression analysis, $\mathrm{BrAC}$ was the independent variable (x), and BAC (or cBAC) the dependent variable (y), as follows:

$$
y=a * x+b
$$

where $a$ is the slope and $b$ is the y intercept.

For the analysis of data from the first part of the study, we also used the Bland-Altman plot to calculate bias and imprecision for $\mathrm{cBAC}$ and $\mathrm{BrAC}$, as follows: bias $\pm 1.96 * \sigma$

[Eq.3]

where $\sigma$ represents standard deviation.

\section{RESULTS AND DISCUSSION}

\section{The retrospective study}

Blood and urine alcohol concentration ratios showed that alcohol was in its elimination phase in all recorded offenders (alcohol concentration in urine $>$ alcohol concentration in blood) at the time BrAC was measured. Individual BrACs were between 0.2 and $4.2 \mathrm{~g} \mathrm{~kg}^{-1}$.

Figure 1 shows the association between the BrAC and cBAC for the 714 analysed samples. Twenty-seven out of 714 samples fell out of the $95 \%$ confidence interval (Figure 1). Using the linear regression analysis we obtained a regression line $\mathrm{cBAC}=0.9385 \mathrm{BrAC}+0.1185$, with a coefficient of determination $\mathrm{R}^{2}=0.912$. A corresponding $95 \%$ confidence interval line was $c B A C \pm 0.41 \approx 0.9385 B r A C$ +0.1185 .

Figure 2 shows the agreement between the two measurement techniques (established with the BlandAltman plot). The observed bias of 0.02 shows that the cBAC was slightly higher than BrAC, which is in accordance with literature reporting longer elimination with higher BAC than $\operatorname{BrAC}(21,22)$.

Median time that elapsed between breath testing and blood sampling was 63.58 minutes (ranging from 0 to 303

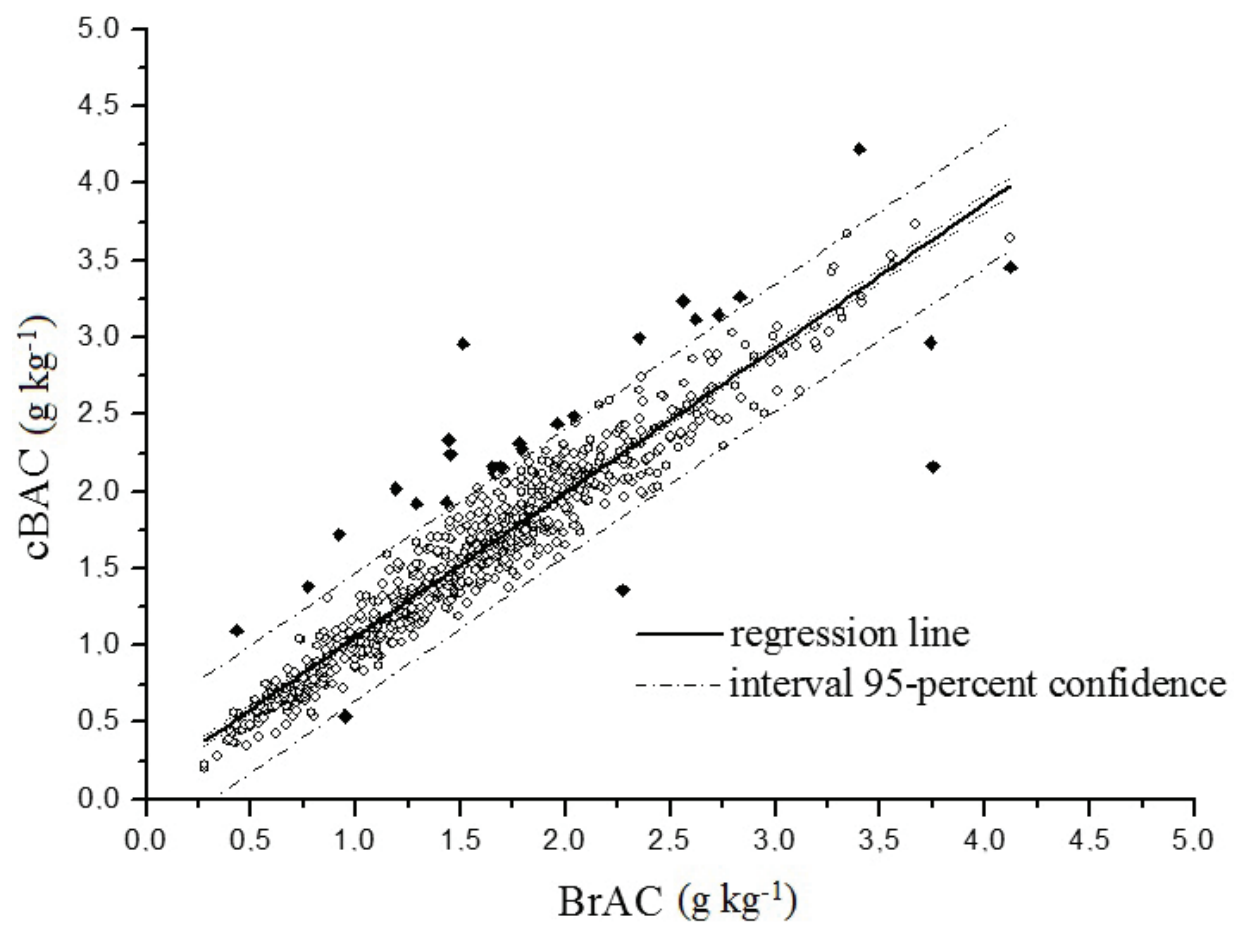

Figure 1 Association between the back-calculated $B A C(c B A C)$ and BrAC measured in 714 subjects in the retrospective part of the study Legend: regression line for $c B A C=0.9385 B r A C+0.1185$ with the coefficient of determination $R^{2}=0.9012 ; 95 \%$ confidence interval (CI) for $c B A C \pm 0.41 \approx 0.9385 \mathrm{BrAC}+0.1185$; symbol o stands for results that fit the CI; symbol stands for results falling outside the CI 


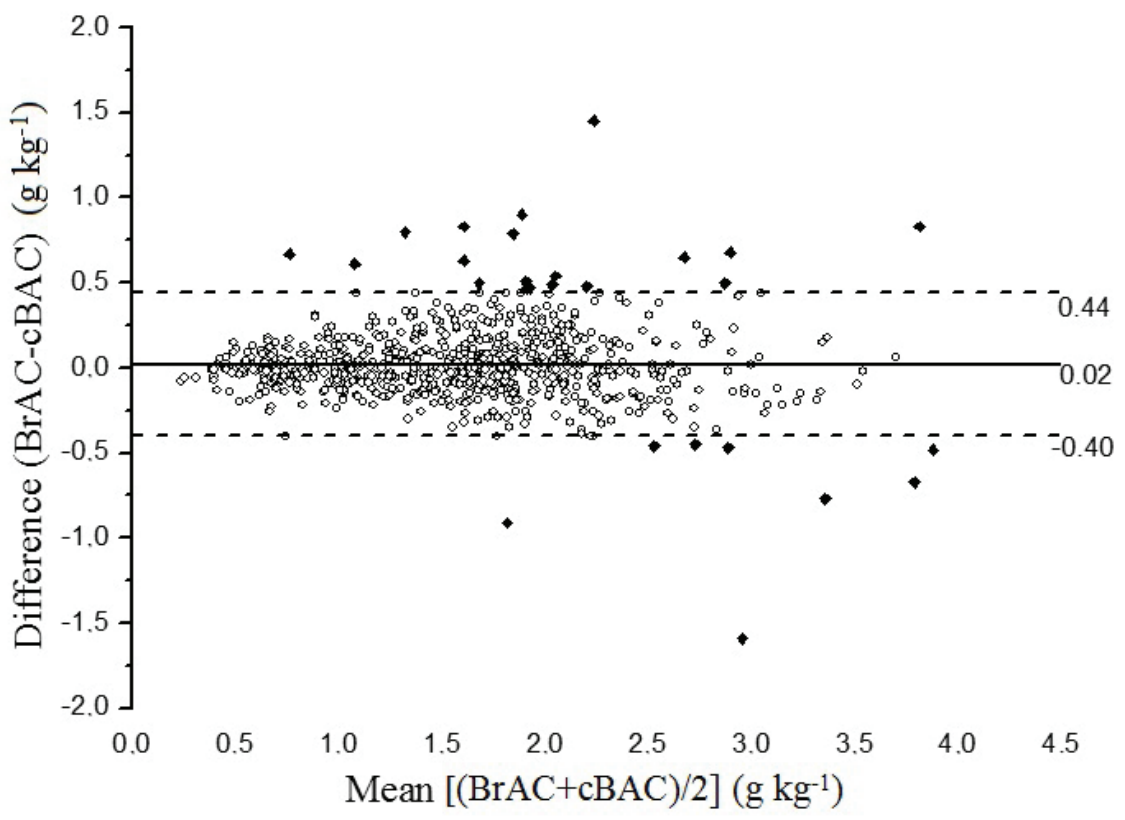

Figure 2 Bland-Altman plot of individual differences $(B r A C-c B A C)$ and mean $[(B r A C+c B A C) / 2]^{*}$

* bold line shows the mean bias and the broken lines show the $95 \%$ confidence interval (bias $\pm 1.96^{*} \sigma$ )

minutes). Table 2 shows mean $\mathrm{cBAC}$ and $\mathrm{BrAC}$ by concentration ranges. We found no statistically significant difference between the two. This high correlation between $\mathrm{cBAC}$ and $\mathrm{BrAC}$ is the main finding of the retrospective part of the study.

There are not many comparable studies that can be used to verify our findings. The most comprehensive among them, which used a similar study design, was the one by Stowell et al. (7). It analysed paired BAC and BrAC in over 11,000 drivers. Roiu et al. (11) reported the results of a similar investigation performed in Germany. Similar to our findings, both studies confirmed the usefulness of the BrAC measurements for BAC estimation.

Our results, however, disagree with the observations outlined in a previous Croatian study by Kovačić et al. (8), who performed a similar research on 570 paired cases of $\mathrm{BrAC}$ and $\mathrm{cBAC}$ and concluded that it was not possible to define the state of alcohol influence using breathalysers. A possible reason for the disagreement between these two studies may have to do with the delay between breath and blood analysis, which is significantly longer (0-1020 min) in the study by Kovačić et al. (8) than in our study (0$303 \mathrm{~min}$ ). This probably led to a less reliable backcalculation. This factor was also reported as important by Stowell et al. (7), who confirmed that delays between breath testing and blood sampling might influence the measurements. Delays between breath and blood sampling in their study ranged from 0.17 to $3.18 \mathrm{~h}$.

In other words, if BrAC is used for back-calculation, BAC seems to be strongly influenced by the delay between the two measurements. To further prove our point, we performed the second part of the study, which is a real-case scenario. The obtained results fit well with the findings of the retrospective part of the study.

\section{The controlled drinking study}

Median time that elapsed between breath testing and blood sampling was 2.82 minutes (ranging from 0 to 14 minutes) in the first stage and 4.3 minutes (ranging from 0 to 23 minutes) in the second stage of the experiment.

Figure 3 shows the association between BAC and BrAC measured in 63 participants in the first stage.

Figure 4 shows the association between BAC and BrAC measured in the 29 participants in the second stage of the controlled drinking study (refers to the alcohol concentrations measured one hour after the first sampling).

Individual BACs ranged between 0.07 and $2.06 \mathrm{~g} \mathrm{~kg}^{-1}$. Individual BrACs ranged between 0.08 and $1.87 \mathrm{~g} \mathrm{~kg}^{-1}$.

Table 3 shows that the BAC and BrAC means in the participants of both stages did not differ significantly. This is the most important finding of the controlled drinking

Table 2 Retrospective study findings of $c B A C$ and BrAC in 714 paired cases

\begin{tabular}{cccc}
\hline Concentration range $\left(\mathbf{g ~ k g}^{-1}\right)$ & $\mathbf{c B A C} \pm \mathbf{S D}$ & $\mathbf{B r A C} \pm \mathbf{S D}$ & Number of samples \\
\hline $0-0.50$ & $0.45 \pm 0.18$ & $0.42 \pm 0.01$ & 20 \\
\hline $0.51-1.50$ & $1.09 \pm 0.35$ & $1.04 \pm 0.29$ & 304 \\
\hline $1.51-2.50$ & $1.92 \pm 0.29$ & $1.90 \pm 0.25$ & 325 \\
\hline$>2.5$ & $2.85 \pm 0.41$ & $2.95 \pm 0.40$ & 65
\end{tabular}

BrAC-breath alcohol content (mass fraction); cBAC-back-calculated blood alcohol content (mass fraction); SD - standard deviation 


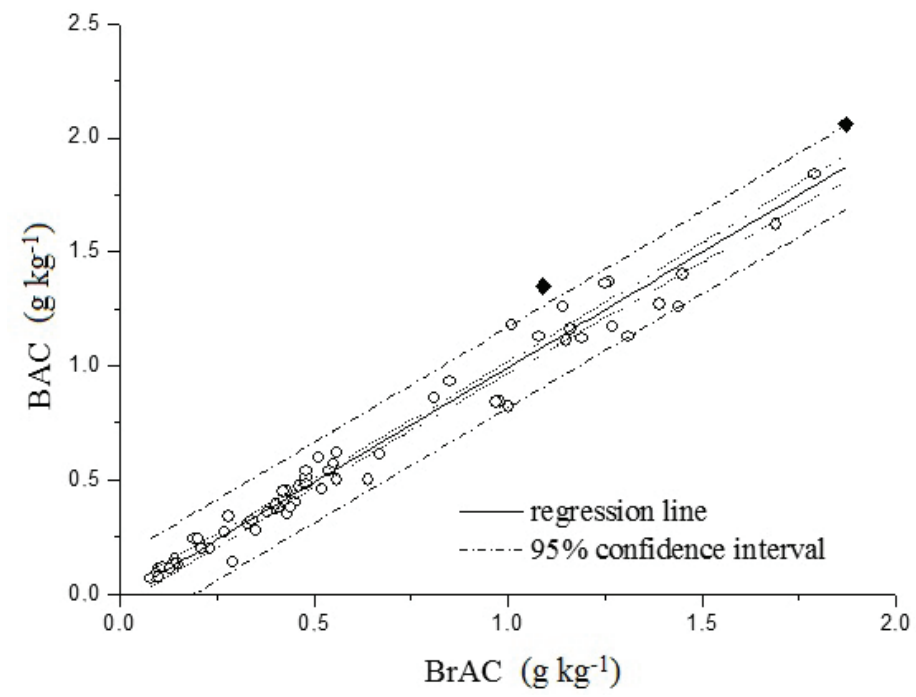

Figure 3 Association between $B A C$ and BrAC measured in 63 subjects in the first stage of the controlled drinking part of the study Legend: regression line for $B A C=1.0084 B r A C-0.0142$ with the coefficient of determination $R^{2}=0.9704 ; 95 \%$ confidence interval (CI) for $B A C \pm 0.177 \approx 1.0084 B r A C-0.0142$; symbol o stands for results that fit the CI; symbol stands for results falling outside the CI

Table 3 Blood alcohol content (BAC) and breath alcohol content (BrAC) in the controlled drinking study

\begin{tabular}{ccccc}
\hline Sampling & \multicolumn{2}{c}{ Stage 1 } & \multicolumn{2}{c}{ Stage 2 } \\
\hline Parameter & BAC $\left(\mathbf{g ~ k g}^{-1}\right)$ & BrAC $\left(\mathbf{g ~ k g}^{-1}\right)$ & BAC $\left(\mathbf{g ~ k g}^{-1}\right)$ & BrAC $\left(\mathbf{g ~ k g}^{-1}\right)$ \\
\hline Mean \pm SD $(\mathrm{SE})$ & $0.68 \pm 0.50(0.06)$ & $0.68 \pm 0.49(0.06)$ & $0.83 \pm 0.46(0.08)$ & $0.74 \pm 0.41(0.07)$ \\
\hline No. of subjects & 63 & 63 & 29 & 29 \\
\hline
\end{tabular}

SD - standard deviation; $S E$ - standard error

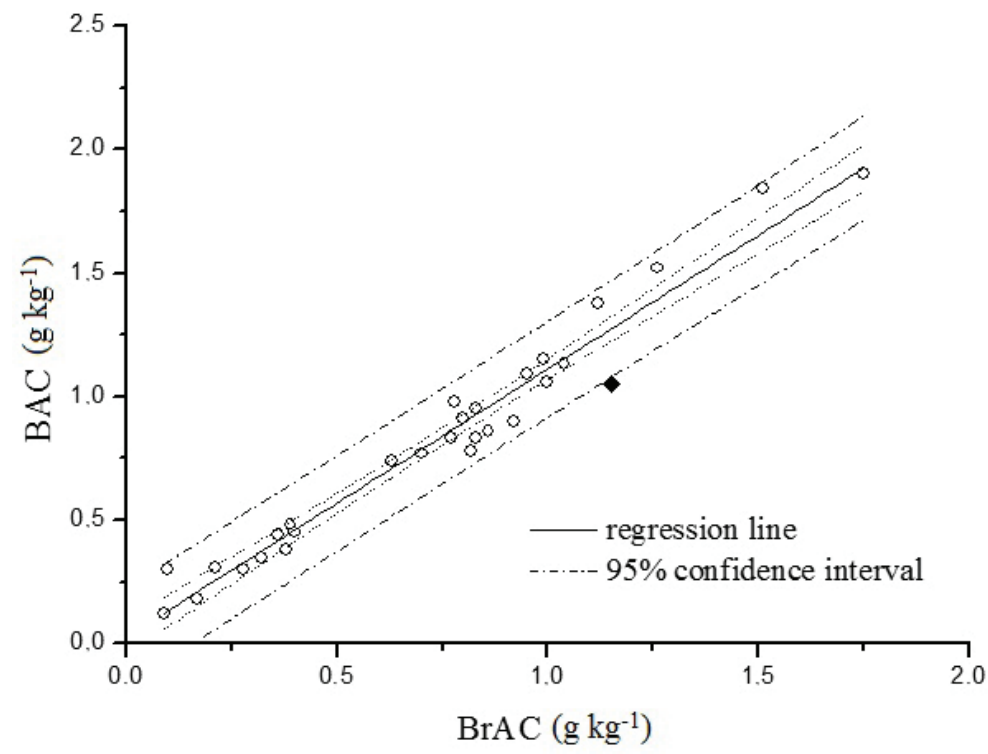

Figure 4 Association between BAC and BrAC measured in 29 subjects in the second stage of the controlled drinking part of the study Legend: regression line for $B A C=1.00846 B r A C+0.0261$ with the coefficient of determination $R^{2}=0.9617 ; 95 \%$ confidence interval (CI) for $B A C \pm 0.195 \approx 1.0846 B r A C+0.0261$. Symbol o stands for results that fit the CI; symbol stands for results falling outside the CI 
Table 4 Alcohol elimination factors ( $\beta$ ) calculated for 21 participants in the controlled drinking study

\begin{tabular}{cccc} 
Analysed sample & \multicolumn{3}{c}{ Elimination factor $\mathbf{( \mathbf { g ~ k g } ^ { - 1 } \mathbf { ~ h } ^ { - 1 } )}$} \\
\cline { 2 - 4 } & Women $(\mathbf{N}=\mathbf{1 4})$ & Men $\mathbf{( N = 7 )}$ & All subjects $(\mathbf{N}=\mathbf{2 1})$ \\
\hline \multirow{2}{*}{ Blood } & $0.12 \pm 0.03$ & $0.18 \pm 0.09$ & $0.14 \pm 0.06$ \\
& $(0.08$ to 0.17$)$ & $(0.08$ to 0.37$)$ & $(0.08$ to 0.37$)$ \\
\hline \multirow{2}{*}{ Expired air } & $0.16 \pm 0.04^{*}$ & $0.18 \pm 0.08$ & $0.17 \pm 0.59$ \\
& $(0.10$ to 0.25$)$ & $(0.06$ to 0.30$)$ & $(0.06$ to 0.30$)$ \\
\hline
\end{tabular}

Results are expressed as mean $\pm S D$ (first row), and range (min-max) of the calculated $\beta$ (second row)

${ }^{*}$ statistically significant difference $(t=2.05 ; P<0.05)$

study, which speaks in favour of the reliability of BrAC determined with a Dräger breathalyser model 6810 (used by the Croatian police on the spot) for the back calculation of blood alcohol concentration.

Similar results were reported by studies comparing BrAC measured with various devices and BAC. Zuba (23) tested BrAC on portable alcoholmeters (Alcotest 7410-Dräger, AlcoSensor IV-Intoximeters) and stationary devices, which measure BrAC through infrared absorption (Alcomat-Siemens and breathalyser A2.0-AWAT). He concluded that the correlation between $\mathrm{BrAC}$ and $\mathrm{BAC}$ was acceptable and that $\mathrm{BrAC}$ could be used if police officer strictly stick to the procedures and calibrate the instruments regularly.

However, there are studies that did not establish this agreement between BrAC and BAC. Vukovic et al. (19) reported that $\mathrm{BAC}$ and $\mathrm{BrAC}$ might significantly differ if alcohol was in its absorption and distribution phase at the time of measurement (15-45 minutes after intravenous alcohol exposure). The authors compared BrAC and BAC in ten volunteers with BAC below to the legal $0.5 \mathrm{~g} \mathrm{~kg}^{-1}$ limit and found significant differences between them. However, when the BAC measurements were repeated after 60 minutes (during the alcohol elimination phase), the difference between $\mathrm{BAC}$ and $\mathrm{BrAC}$ was gone.

The Forensic Science Centre Ivan Vučetić estimated that less than $4 \%$ of the people screened for BrAC in 2011 were still in the alcohol absorption and distribution stage when they took the test. Our controlled drinking part of the study has confirmed no significant differences between $\mathrm{BAC}$ and $\mathrm{BrAC}$, even though a significantly higher proportion (34.92\%) of the participants were in the alcohol absorption and distribution stage. A reason for this may lie in the distribution and elimination of alcohol. Moore (21) claims that the first all BrAC measurements should observe the 15 minute waiting time to make sure there is no mouth alcohol. Over these 15 minutes, the blood-to-breath ratio increases to $1: 2100$ due to alcohol distribution and elimination, which means lower BrAC than BAC (25-28).

Blood-to-breath ratio depends on many factors such as sex, physical activity and breathing, and body temperature. This is why the conversion factor can vary from 1:1800 to $1: 2300$. The largest variation is when one starts drinking alcohol, that is, when alcohol is in its absorption phase. Then the conversion factor (ratio of venous/arterial blood) may be 1:1800, which results in a higher BrAC (arterial blood flow) than BAC (venous blood flow) (22). Some authors (24-26) suggest that the BrAC better reflects brain exposure to alcohol than venous blood alcohol. This is especially evident during the absorption phase, when alcohol effects are the most prominent and drunk drivers run the greatest risk of accident.

Twenty-one of the 29 stage 2 participants were in the alcohol elimination phase (their urine alcohol was higher than BAC). For these participants we further calculated the alcohol elimination factor $(\beta)$ according to Widmark's formula (Table 4) $(17,18)$. Women had a significantly better elimination from blood than from the exhaled air. These findings have already been reported earlier (29-31). Our findings, however, are somewhat limited by the small population, and further investigation with a larger sample is needed to obtain a better insight into the differences in alcohol elimination from blood and exhaled air between women and men.

\section{CONCLUSION}

We have shown a high correlation between $\mathrm{BrAC}$ and BAC in both parts of the study. These results allow us to conclude that breathalysers are as reliable for backcalculation as are the BAC obtained by GC-FID-HS method when there is available only one sample of blood and data about the time, type, and volume of consumed alcoholic beverage available.

The advantage of measurement with the Dräger Alcotest $7410^{\text {Plus }}$ and 6810 is that this is a quick, accurate, and noninvasive method. Its disadvantage is that, unlike with blood samples, the measurement cannot be repeated (32). As long as the police follow manufacturer's instructions (take measurements at least 15 minutes after alcohol consumption), the measurement error is minimal.

Nevertheless, to compensate the weaknesses of BrAC testing, the complementary measurements of alcohol concentrations in other biological matrices are advisable whenever possible.

\section{Acknowledgement}

We thank all the employees of the Police Directorate of the Ministry of the Interior who volunteered to participate in this study. A special thanks is due to Dr Irena Brčić Karačonji, who guided us expertly through this paper. 


\section{REFERENCES}

1. Zakon o sigurnosti cestovnog prometa [Road Traffic Safety Act, in Croatian]. Narodne novine 67/2008.

2. Ministarstvo unutarnjih poslova Republike Hrvatske (MUP RH). Bilten o sigurnosti cestovnog prometa 2011 [2011 Bulletin of Road Safety, in Croatian]. Zagreb: MUP RH; 2012.

3. Ministarstvo unutarnjih poslova Republike Hrvatske (MUP RH). Bilten o sigurnosti cestovnog prometa 2015. [2015 Bulletin of Road Safety, in Croatian]. Zagreb: MUP RH; 2016.

4. Pavlic M, Grubwieser P, Libiseller K, Rabl W. Elimination rates of breath alcohol. Forensic Sci Int 2007;171:16-21. doi 10.1016/j.forsciint.2006.09.008

5. Lindberg L, Brauer S, Wollmer P, Goldberg L, Jones AW, Olsson SG. Breath alcohol concentration determined with a new analyzer using free exhalation predicts almost precisely the arterial blood alcohol concentration. Forensic Sci Int 2007;168:200-7. doi: 10.1016/j.forsciint.2006.07.018

6. Jachau K, Wittig H, Heres F, Krause D. Concurrent Measurements of Arterial and Venous Blood Alcohol Concentrations and Breath Alcohol Concentrations Using the Alcotest 7110 MK III Evidential. Magdeburg: Institute of Forensic Medicine, Otto-von-Guericke-University [displayed 14 March 2018]. Available at http://tiaft2006.slonic.net/ proceedings/pdf/BT-p-02 full.pdf

7. Stowell AR, GainsfordAR, Gullberg RG. New Zealand's breath and blood alcohol testing programs: further data analysis and forensic implications. Forensic Sci Int 2008;178:83-92. doi: 10.1016/j.forsciint.2008.02.005

8. Kovačić Z, Nestić M, Stemberga V, Bosnar A, Petrovečki M, Sutlović D. Reliability of breath alcohol testing with Dräger Alcotest $7410^{\text {Plus }}$ analyzer in a court process. Med Jad 2008;38:47-51.

9. Gainsford AR, Fernando DM, Lea RA, Stowell, AR. A largescale study of the relationship between blood and breath alcohol concentrations in New Zealand drinking drivers. J Forensic Sci 2006;51:173-8. doi: 10.1111/j.1556-4029. 2005.00029.x

10. Dettling A, Witte S, Skopp G, Graw M, Haffner HT. A regression model applied to gender-specific ethanol elimination rates from blood and breath measurements in non-alcoholics. Int J Legal Med 2009;123:381-5. doi: 10.1007/s00414-0080282-y

11. Roiu I, Birngruber CG, Spencer VC, Wollersen H, Dettmeyer $\mathrm{R}$, Verhoff MA. A comparison of breath- and blood-alcohol test results from real-life policing situations: a one-year study of data from the Central Hessian police district in Germany. Forensic Sci Int 2013;232:125-30. doi: 10.1016/j. forsciint.2013.07.002

12. Trafford DJ, Makin HL. Breath-alcohol concentration may not always reflect the concentration of alcohol in blood. J Anal Toxicol 1994;18:225-8. doi: 10.1093/jat/18.4.225

13. Simson G. Accuracy and precision of breath alcohol measurements for subjects in the absorptive state. Clin Chem 1987;33:753-6. PMID: 3594808

14. Simson G. Do breath tests really underestimate blood alcohol concentration? JAnal Toxicol 1989;13:120-3. PMID: 2604767

15. Pravilnik o načinu i postupku vađenja krvi i uzimanja mokraće za analizu radi utvrđivanja koncentracije alkohola, opojnih droga i psihoaktivnih tvari [Ordinance on blood and urine sampling for measuring the levels of alcohol, drugs of abuse, and psychoactive substances, in Croatian]. Narodne novine 107/1999.
16. Pravilnik o mjeriteljskim zahtjevima za uređaje kojima se mjeri udio etilnog alkohola u izdahu ispitanika [Ordinance on metrological requirements for breath-alcohol concentration measuring instruments of subjects, in Croatian]. Narodne novine 118/1999.

17. Labianca DA. Estimation of blood-alcohol concentration. J Chem Educ 1992;69:628-2. doi: 10.1021/ed069p628

18. Posey D, Mozayani A. The estimation of blood alcohol concentration Widmark revisited. Forensic Sci Med Pathol 2007;3:33-9. doi: 10.1385/FSMP:3:1:33

19. Vukovic J, Modun D, Markovic D. Comparison of breath and blood alcohol concentrations in a controlled drinking study. J Subst Abus Alcohol 2015;3:1029.

20. Periša J, Tijardović M. Određivanje niskih koncentracija etanola $(<0,5 \mathrm{~g} / \mathrm{L})$ u slini, serumu i urinu nakon konzumacije alkoholnih pića [Determination of low concentrations of ethanol $(<0.5$ $\mathrm{g} / \mathrm{L}$ ) in saliva, serum and urine after consumption of alcoholic beverages]. Zagreb: Farmaceutsko-biokemijski fakultet Sveučilišta u Zagrebu; 2016.

21. Moore R. Concerning breath alcohol measurements during absorption and elimination. J Anal Toxicol 1991;15:346-7. doi: 10.1093/jat/15.6.346

22. Haffner HT, Graw M, Dettling A, Schmitt G, Schuff A. Concentration dependency of the BAC/BrAC (blood alcohol concentration/breath alcohol concentration) conversion factor during the linear elimination phase. Int J Legal Med 2003;117:276-81. doi: 10.1007/s00414-003-0384-5

23. Zuba D. Accuracy and reliability of breath alcohol testing by handheld electrochemical analysers. Forensic Sci Int 2008;178:e29-33. doi: 10.1016/j.forsciint.2008.03.002

24. Jones AW, Andersson L. Comparison of ethanol concentrations in venous blood and end-expired breath during a controlled drinking study. Forensic Sci Int 2003;132:18-25. doi: 10.1016/ S0379-0738(02)00417-6

25. Martin E, Moll W, Schmid P, Dettli L. The pharmacokinetics of alcohol in human breath, venous and arterial blood after oral ingestion. Eur J Clin Pharmacol 1984;26:619-26. doi: 10.1007/ BF00543496

26. Jones AW, Simpson G. Concerning accuracy and precision of breath-alcohol measurements. Clin Chem 1987;33:1701-6.

27. Jones AW. Evidential breath alchol analysis and the venous blood-to-breath ratio. Forensic Sci Int 2016;262:e37-9. doi: 10.1016/j.forsciint.2016.03.008

28. Simic M, Tasic M. The relationship between alcohol elimination rate and increasing blood alcohol concentration - Calculated from two consecutive blood specimens. Forensic Sci Int 2007;172:28-32. doi: 10.1016/j.forsciint.2006.11.008

29. Taylor L, Dolhert N, Friedman L, Mumenthaler M, Yesavage JA. Alcohol elimination and simulator performance of male and female aviators: a preliminary report. Aviat Space Environ Med 1996;67:407-13. PMID: 8725465

30. Seidl S, Jensen U, Alt A. The calculation of blood ethanol concentrations in males and females. Int $\mathrm{J}$ Legal Med 2000;68:71-7. doi: 10.1007/s004140000154

31. Jones AW, Andersson L. Influence of age, gender, and bloodalcohol concentration on the disappearance rate of alcohol from blood in drinking drivers. J Forensic Sci 1996;41:922-6. doi: 10.1520/JFS14026J

32. Ferček R. Testiranje sudionika u prometu [Testing for toxicants in traffic, in Croatian]. In: Sutlović D, editor. Osnove forenzične toksikologije [Principles of Forensic Toxicology, in Croatian]. Split: Redak; 2011, p. 211-28. 


\section{Procjena pouzdanosti uređaja za mjerenje koncentracije etanola u izdahnutom zraku usporedbom s koncentracijom etanola u krvi}

Cilj ovog istraživanja bio je utvrditi pouzdanost alkometara kojima se trenutačno koristi hrvatska policija. Prvi dio istraživanja obuhvatio je retrospektivnu analizu 714 podataka prikupljenih tijekom 2011. godine. Uzorci krvi za određivanje koncentracija etanola u krvi (BAC) prikupljeni su najkasnije 303 minute nakon mjerenja koncentracije etanola u izdahu $(\mathrm{BrAC})$ te su preračunati na vrijeme mjerenja $\mathrm{BrAC}(\mathrm{cBAC})$ kako bi se procijenila preciznost alkometara. Svi sudionici bili su u fazi eliminacije etanola, a naše analize nisu otkrile statistički značajne razlike između cBAC-a i BrAC-a. Da bismo potvrdili nalaz, proveli smo drugi dio istraživanja na uzorku od 63 zdrava dobrovoljca koji su konzumirali alkoholna pića. Netom nakon konzumacije alkohola BrAC je određen Drägerovim alkometrom marke 6810, a 29 sudionika dalo je uzorak krvi i urina za istu analizu sat vremena poslije. BAC i koncentracije alkohola u mokraći određeni su plinskom kromatografijom (HS-GC-FID). Ni u ovom istraživanju nismo pronašli statistički značajnu razliku između BrAC-a i BAC-a. Ovi rezultati potvrdili su visoku pouzdanost alkometara koji mjere BrAC, pod uvjetom da policijski službenici obavljaju mjerenja prema uputama proizvođača.

KLJUČNE RIJEČI: alkometar; čimbenik eliminacije; plinska kromatografija; pouzdanost metode; retroaktivni izračun koncentracije alkohola 